\title{
Media Adaptation of Mask Making in Malang: Study of Functional and Process for Making Fiber Masks
}

\author{
Izam Ismail ${ }^{\mathrm{a}, 1, *}$ \\ ${ }^{a}$ Pasca Sarjana Universitas Negeri Surabaya, Indonesia \\ 1 izamismail92@gmail.com* \\ * Corresponding Author
}

Received; 2020-11-20

accepted; 2021-10-12

published 2021-11-26

\begin{abstract}
The mask is the main attribute in Malang Mask Show. The representation of Malang masks has undergone adaptation along with the development of the times, which were originally made of wood. This study aims to analyze the Malang mask material from the adaptation process of fiber raw materials as its component. The research approach method is descriptive qualitative. Data collection techniques using observation and interviews as the unit of analysis descriptively. The results of the study on the adaptation of the raw material for making Malang masks from wood into fiber as a medium of learning and the preservation of local culture as a medium of learning in schools. The technique of making Malang masks with fiber material uses the basic principles of printing and finishing techniques in the painting process using acrylic paint. An important finding from this research is that the Malang Mask making material using fiber has long durability, does not rot because it is synthetic.
\end{abstract}

\section{KEYWORDS}

Mask

Adaptation;

Malang Mask

Fiber;

Priting technique

This is an open access article under the CC-BY-SA license

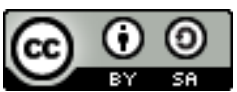

\section{Introduction}

Javanese culture from an early age by campaigning for the use of the Javanese language in nonformal events, looking for stimulants that can balance technological advances by revitalizing Javanese ritual cultural customs, and conducting healthy communication between fellow citizens; the second factor is physical culture (Fitriyani and Susilowati 2019). The Padepokan Asmoro Bangun arts group started from the generation of Serun with the name Pandawa Lima in 1880-1917 (Wibowo, Kurnain, and Juanda 2020). Appreciation for certain masks is manifested in the form of the Wayang Topeng Dance Drama performance. The Malang Mask Wayang Dance drama is a mask performance that depicts several characters in the Panji story. The Panji story is a corpus of stories from the Kingdom of Kediri from East Java, with the theme of heroism and love centered on the characters Panji Asmorobangun and Dewi Sekartaji during the Majapahit Kingdom in East Java (around 1300 to 1500) (Rahayuningtyas et al. 2019). It contained heroism and romance centered on two main figures, namely Raden Inu Kertapati or Panji Asmarabangun, and Dewi Sekartaji or Galuh Candrakirana (Budiarto 2019). A prince from the Janggala Kingdom by the name of Panji Inu Kertapati (the incarnation of Kamajaya) and a princess from the Kingdom of Kediri by the name of Galuh Candrakirana or Sekartaji (the incarnation of Dewi Ratih) are the main figures in the story, and play key roles in the division of the kingdom after the deathof King Airlangga (L. Kieven 2020). In the past, Malang mask puppets developed and developed in several districts in Malang such as Dampit, Precet, Wajak, Ngajum, Jatiguwi, Senggreng, Pucansanga, Jabung and Kedungmonggo, but now there are only four wayang masks. groups that are still active and three of them are downsizing, and now there are only four puppet mask groups left (Suprihatin Dyah Pratamawati 2016).

The Malang Mask Puppet Dance Drama in Malang Regency, the inheritance of the values of Malang Mask Puppet Dance Drama at the Asmoro Bangun Topeng Hermitage, Kedungmonggo Village, Pakisaji District, Malang Regency. Taking the stories of the Ramayana and Mahabharata Epics presented on Malang masks, the public is less interested in turning them into Panji stories. Poetic literature flourished with both Indian based stories (kakawin) and indigenous stories (kidung). Language, metre, story plots and the protagonists of kakawin drawback on Indian Sanskrit literature, especially the Ramayana and the Mahabharata epics (L. C. Kieven 2017). The absorption of Indian 
culture by the Indonesian people can initiate the transformation of the function of the mask, which can be actualized through innovative modifications (Hidajat et al. 2019). The values of Mask Puppet Dance-Drama should be used as the principle when facing the other values. The technological advance could influence behavior, in this case, is cultural behavior (Rahayuningtyas et al. 2019). The art element in the Malang mask is clearly visible in the visualization of the mask which is the main attribute in the Malang mask dance performance. The Panji tradition was considered a specific bearer of local genius and local wisdom, and was thought to be particularly suited to be a medium for conveying and enacting these purposes. As it is primarily manifest in folk- like forms, it was categorized as part of the culture of common people (L. Kieven 2020). The form of Malang masks was 'produced' to express the different figures in the narration of the Panji story (Guntur 2021). The Malang mask itself has the Panji character which is visualized in the mask. Panji characters such as Klana Sewandana, Panji Asmarabangun, Gunungsari, Bapang, Ragel Kuning, Sekartaji, and Sabrang soldiers are made into masks with wood media through a carving process. Making Malang masks from raw materials or wood media requires a long process by going through various stages of manufacture.

Masks provide insight into everyday life, both past and present. By providing an oral explanation of the mask, they are offered in-depth exploration, their self-perception of the mask, as well as the challenges and opportunities in long-term reintegration. The mask-making process ultimately provided the team with richer contextual information about modern masks. Similarly, doing the making of this Malang banner mask (Green and Denov 2019). The process of modernization provides an overview of the shift in human thought that no longer ignores the traditional values of a culture. Reflected traditional values become a culture. In the past, all value reflections were controlled by tradition, but now it is personal reflection that controls tradition, maintains, reconsiders its value, decides to adopt it again while maintaining the value or changing it. Modernization also encourages changes in Malang Mask. The growth of moderate Islam and the development of modernism influence the changing function of the Malang mask puppet. Padepokan Seni Asmoro Bangun, is located at Kedungmonggo Hamlet, Pakisaji, Malang regency, one of the art studios which still maintains Malang mask puppet (Wibowo 2019). In addition to being used for figuration of roles in a performance, Malang masks are also art objects which possess visual characteristics that are interesting and vital to study, in order to learn about local knowledge, and at the same time to appreciate the status of the mask as a visual art tradition (Guntur 2021). Nowadays, Malang Mask is developed from fiber media. The emergence of Malang Mask with fiber material is an implication of the explosion in demand for mask distribution. The impetus to find out the adaptation of the media used in making Malang masks and its influence on the philosophy of Malang Masks and the process of making Malang masks using fiber media has brought researchers interested in studying. In addition to being a performance, Wayang Topeng Malang also serves as a guide that teaches the norms and values of everyday life. The role of the Wayang Topeng Malang is considered quite significant in the present, but ironically, most adolescents in Malang does not know about it (Novica et al. 2020).

\section{Method}

This research is a qualitative research, namely the data obtained will be described descriptively in the form of words or sentences. The study used data exposure in the form of oral statements and the interpretation of the actions of the informants obtained directly. The essence of qualitative research is to understand phenomena in the natural environment which correspond to the experimental setting in quantitative research, where all aspects (variables/parameters) are examined under experimental conditions (Alhamdani 2016). This study integrates art-based qualitative data collection methods (Green and Denov 2019). Data collection was done by interview and observation. Key informants are Agus Eko (30 years) an artist and teacher, Eko Budiyono (32 years) a fiber mask craftsman. The data were obtained from in-depth interviews, especially in the adaptation process of making Malang Masks with fiber materials. Although there are several approaches to-based art research, for research purposes we explore materials with the following processes; (a) drawing. (b) mask making. Which then examines the process, strengths, and limitations of this art-based method specifically in the context of our research (Green and Denov 2019). The analysis uses interpretative and is written descriptively. 


\section{Results and Discussion}

\subsection{Mask Adaptation}

Malang masks have been popular since the Reni era. Reni herself is a Malang Mask artist from Palawijen Hamlet. The Malang mask has become a culture that shows the characteristics and character of the banner attached to the visualization of the mask. The Malang Mask performance has a sequence of presentations from a combination of various elements of art (sound, music, dance, painting, sculpture, and performance). The tradition of masked dance functions as worshipping was being considered as a medium to free humans from danger and get protection from their ancestor (Wibowo 2019). Malang Mask is a mask using wood as a basic material with a visual form of the Panji character. The mask is an element or property in the Malang Mask performance, used by dancers. The figure of the banner is described as a knight who has an example in living life (tuladha main practice). The image of the Nusantara hero is depicted in the figure of Panji who is played in the Malang Mask show. Conservation strategies carried out in the Studio include maintenance, guidance, management, and protection. Maintenance is carried out by maintaining the sustainability of the studio activities, both in the field of performance and also arts (making the Malang Mask) (Suprihatin and Pratamawati 2019). In terms of time, the Malang Mask underwent cultural changes as a form and aspect of values that developed in society. The Malang mask is symbolic, a reflection of cultural symbols that have meanings that can be used as models and educational media for today's society, in family, politics, and leadership succession (Raharjo, Supratno, and Sudikan 2020). Mask Malang along with the development of science and culture undergoes changes and adaptations both in terms of presentation, form and packaging in performances as well as materials and materials in making masks. In this study, researchers will focus on media adaptation in making Malang Masks. According to Eko Budiyono, the number of orders received requires mask craftsmen, especially in the City and Regency of Malang to look for alternative media that will be used as raw materials for making masks. According to Agus Eko, as an art teacher as well as a cultural observer, changes and adaptations are natural in today's culture. The shift in meaning and an open and logical human perspective overrides the spiritual side that is the lifeblood of a culture. Currently, the shift in view must be interpreted as a directed change, so that even though it changes, it does not change the basic values of philosophy in the presentation of the show. Adaptation of media for making masks using fiber is a positive step when it comes to cultural preservation efforts in the realm of art education. The year 2016 was the beginning of the ideas and thoughts of Eko Budiyono to adapt new media and materials as materials in making Malang Masks. Eko Budiyono is a craftsman and property cultivator in the field of performance. At first, Eko Budiyono received 300 orders for the cultivation of Malang Masks (the Sabrang type). The drive for need triggers adaptation. Initially, Eko Budiyono found it a little difficult to receive orders in large quantities and in a relatively short period of time. Adaptation of materials or media in making Malang Masks in Table 1 is carried out by conducting several experiments and possibilities.

Table 1. Media Exploration

\begin{tabular}{|c|c|c|c|c|}
\hline \multirow{2}{*}{ Indicator } & \multicolumn{4}{|c|}{ Media Evaluation } \\
\hline & wood & Fiber & paper & Foam \\
\hline $\begin{array}{l}\text { Easy to find } \\
\text { ingredients }\end{array}$ & Dificult & $\begin{array}{l}\text { Mudah didapatkan } \\
\text { di toko kimia }\end{array}$ & $\begin{array}{c}\text { Sangat mudah didapatkan } \\
\text { di toko loak }\end{array}$ & $\begin{array}{c}\text { Mudah didapatkan } \\
\text { di toko ATK }\end{array}$ \\
\hline $\begin{array}{l}\text { Time or process of } \\
\text { making } 1 \text { mask }\end{array}$ & $\begin{array}{l}\text { More than } 1 \\
\text { month }\end{array}$ & 1 day & $\begin{array}{l}2 \text { days depends on } \\
\text { weather }\end{array}$ & 1 day \\
\hline Durability & $\begin{array}{l}\text { Good but can get } \\
\text { old }\end{array}$ & $\begin{array}{l}\text { Good and can't be } \\
\text { weathered }\end{array}$ & $\begin{array}{l}\text { Not good is easy to } \\
\text { damage }\end{array}$ & $\begin{array}{l}\text { Good but the } \\
\text { shape of the } \\
\text { ornament can't be } \\
\text { as detailed as the } \\
\text { original }\end{array}$ \\
\hline Cost & Expesive & affordable & Cheap & affordable \\
\hline Shrinkage & $\begin{array}{l}\text { It doesn't shrink } \\
\text { but when the } \\
\text { wood has been } \\
\text { processed it tends } \\
\text { to lose weight }\end{array}$ & $\begin{array}{l}\text { No shrinkage and } \\
\text { the same initial and } \\
\text { final }\end{array}$ & $\begin{array}{l}\text { shrinkage from the initial } \\
\text { size }\end{array}$ & $\begin{array}{c}\text { Not shrinking but it } \\
\text { can be said to be } \\
\text { very light }\end{array}$ \\
\hline Details & $\begin{array}{c}\text { You can but need } \\
\text { a process }\end{array}$ & $\begin{array}{l}\text { Could be because of } \\
\text { the printed liquid }\end{array}$ & $\begin{array}{l}\text { You can but it's a bit } \\
\text { difficult and requires a }\end{array}$ & $\begin{array}{l}\text { Can but requires a } \\
\text { process of cutting }\end{array}$ \\
\hline
\end{tabular}

Izam Ismail et al. (Media Adaptation of Mask Making in Malang...) 


\begin{tabular}{lcccc}
\hline \hline \multirow{2}{*}{ Indicator } & \multicolumn{4}{c}{ Media Evaluation } \\
\cline { 2 - 4 } & wood & Fiber & paper & Foam \\
\hline & & base material & process & \\
\hline
\end{tabular}

Based on the Table 1, the adaptation process is carried out by considering the materials and media that will be used in making the Malang Mask. Each material has its own advantages and disadvantages. Wood material and the results are good but require a relatively long process in the process. Paper is a material that is easily available and inexpensive but can experience shrinkage which can affect size. Finally, with various considerations, it shows that fiber has the potential to be adopted as a substitute for the raw material for making Malang Masks. Composing process, the mask design, the use of a problem-solving hierarchy to compose the mask so as to prioritize decision-making, the regard of the mask at any point as a provisional text subject to further work, the use of a sketch prior to working on the actual mask, and the generation of a verbal plan to guide production (Barone and Bresler 2000). Since 2016 until now in 2020 the number of requests received by Eko Budiyono to work on fiber masks still exists and is even growing. The demand for the Malang mask with fiber media is very popular, especially for educators and students. Tobeng with fiber material can last a long time and is not easily damaged by using fiber material as reinforcement. Fiber material shortens the processing process when compared to masks made of wood. But again, masks made of fiber, of course, symbolically and philosophically, symbols reflecting socio-cultural aspects (Raharjo, Supratno, and Sudikan 2020).

The demand for fiber masks according to Eko Budiyono is not only in terms of Malang Masks as a medium for performances, but also as festival events and souvenirs in the form of fandels and key chains. This development indicates a change in Malang Mask culture functionally and its role is no longer a sacred element of ritual. The manufacture of fiber masks with various functions has a good purpose in the exploration and promotion of Malang Mask culture to the people of Malang in particular and people outside Malang in general. The adaptation of materials from wood to fiber gives the Malang Mask a role with various functions. The Malang Mask which used to be a sacred performance, but with the adaptation and influence of the media and the development of human thought today, Malang Mask has other roles and functions. This role is in an effort to maintain existence in various functions, not only as a performing art.

\subsection{Mask Making Process}

The process of making Malang Masks was initially carried out at the Kedungmonggo Studio as one of the studios that preserve Malang Mask Arts. Mask craftsmen in Kedungmonggo use wood media with the stages of the process, namely mbakali or making going, wiwit, followed by maraeni, and maesi. On a high level of abstraction 3 strategies can be identified in which fibers are used to produce parts that have mechanical properties that surpass those of the base materials (Vaneker 2017). In contrast to the stages of the process carried out in Kedungmonggo with the basic ingredients of wood, the process of making fiber masks carried out by Eko Budiyono uses a printing technique. The printing technique was chosen because it is suitable for use with liquid materials or materials such as fiber. The stages of the process of making fiber masks are embedding or making molds, printing or filling the molds with fiber, drying and base, finally finishing. Malang masks with fiber materials in the printing process require silicon molds and require materials such as resin, catalyst, gauze or fiber or fiber yarn. With the fiber material, the process of making masks becomes shorter and faster. The print uses a typology of the Malang Mask shape carved in Kedungmonggo which aims to be a standard size used for Malang mask performances.

\subsection{Fiber Mask Making Process}

The manufacture of masks using fiber media was initiated by a craftsman, namely Eko Budiyono, a dance property craftsman at the Asri Kusuma Karawitan Dance Studio, State University of Malang. The manufacture of fiber masks goes through several stages as follows:

- Practice; the machining stage is the initial stage in the manufacture of fiber masks. Pemalan can be defined as the manufacture of molds. At this stage there are several types of methods and materials in making molds. The implementation is done using the original mask made by Kedungmonggo or you can also make your own mask using plasticine. Practice using the 
original mask is done with the aim of obtaining results and details that are similar to the original mask. The original mask is placed on a plywood board with a position facing up. Locked using glue gun so that the position is fixed and does not change. The mask is given a layer of oil so that the media used to make the print does not stick and stick to the mask. There are three types of material choices used in the manufacture of molds, namely gypsum, glass glue, and liquid silicon. In Figure 1. shows how the original mask that has been smeared with oil is then covered with liquid silicone or with glass glue. This is done gradually and must cover everything so that the print can follow the curves of the details on the mask ornament. After drying, the next process is casting the mold with gypsum. Casting aims so that the mold can last a long time and the results are the same and do not change from the mold.

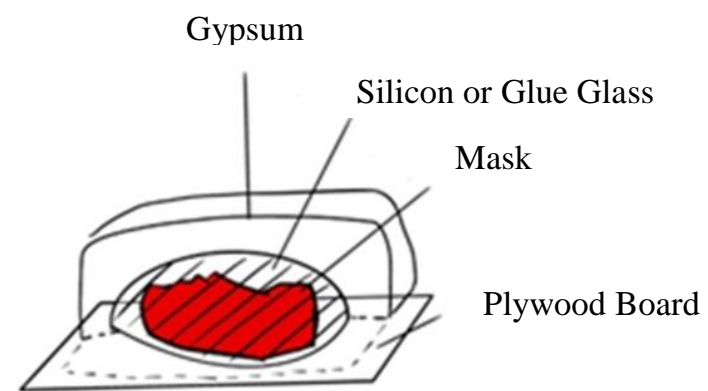

Fig. 1. Mold

- Print; the printing process is the process of pouring resin liquid with sufficient fiber reinforcement so that the mask can last a long time and be strong. At this stage the silicon mold is filled with liquid resin. This is done by pouring resin into the mold little by little and the mold must be continuously rotated. A circular motion is done so that the liquid can enter the small holes or scratches on the mask details. After evenly layering, the addition of fiber yarn as reinforcement. Fiber thread is affixed throughout the mold. After being affixed, it is followed by layering of resin liquid and repeated giving fiber threads to the desired thickness. Usually done 3 to 4 repetitions. After completing the repetition until the desired thickness, the mold is placed on top of the gypsum with the face of the mold facing down.

- Drying and Base; Figure 2, shows the process of the drying step carried out by leaving the mold on gypsum for several hours. Drying is done indoors or outdoors, but provided that it is not exposed to direct sunlight. Sunlight can directly affect the process and printouts. The drying process takes about 1-1.5 hours depending on the place. The drying stage ends with the removal of fibers from the mold, and continues with painting the base. Base is the initial painting process using a mixture of wood glue, calcium, and water or you can also use a white acrylic base.

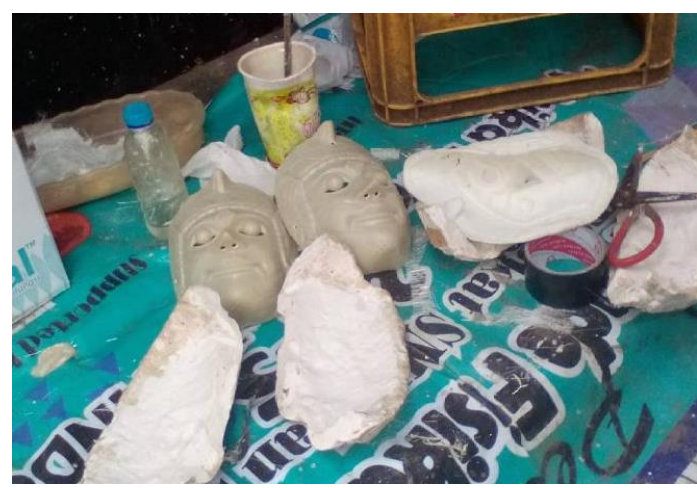

Fig. 2. The process of removing the fiber mask from the mold Finishing 
In Figure 3, describes the finishing process is the last stage in the process of making fiber masks. The final stage is the process of detailing and painting the ornament and all the elements contained in the mask. The process is done by imitating the color details found on the original Kedungmonggo mask. Coloring is done using acrylic paints that are brushed with a small brush. Painting can be done with approximately one full day to achieve the details according to the Kedungmonggo mask. After finishing and drying, the last step is to be given a layer of varnish or you can also use clear.

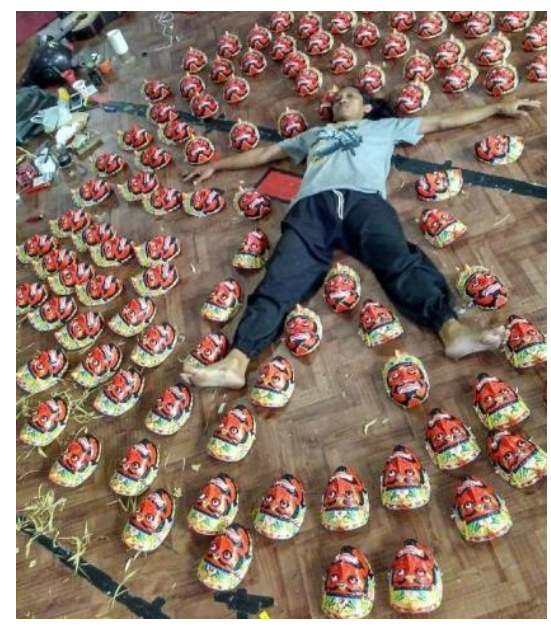

Fig.3. The results of the fiber mask after going through the finishing stages

\section{Conclusion}

Malang mask using fiber material is an adaptation of the development of human thought. Adaptation is done by changing the media without changing the form and visuals that appear in Topeng Malang. The use of fiber media has a different philosophical basis from masks made of wood. The mask in the Malang Mask performance is a sacred form used by dancers by bringing the Panji character in the show. The mask is an important element in the Malang Mask performance. The choice of wood in the making of Malang Mask has sacred and philosophical values in the dance presentation. Malang masks made of fiber are used as learning materials and are an effort to preserve culture that departs from education in schools. By adapting printing techniques and using new media, fiber masks become an alternative for cultural distribution at a relatively affordable price when compared to wooden masks. The affordable price of fiber masks provides encouragement for educators to introduce the culture of the local community in art learning in schools. The stages of making fiber masks begin with practice, which is the process of making molds without changing the shape and ornaments in Malang Masks. Implementing while maintaining the character is one of the efforts to maintain the existing standard even though the raw materials for making it are changed but the visuals remain the same. Then the printing stage is the main process in making fiber masks. In the printing process requires a level of patience so that in pouring the resin liquid does not appear bubbles which will reduce the detail in the printed result. The third stage is drying and foundation, namely the drying process is carried out not under direct sunlight. And after drying, the base is completely white. Then the finishing stage is painting and providing details according to the Malang Mask visual.Hasil topeng fiber setelah melalui tahapan finishing.

\section{References}

Alhamdani, Faaiz. 2016. "An Introduction To Qualitative Research Methodology Artistic Approach." International Journal of Development Research $6 \quad$ (10): 9774-76. https://www.researchgate.net/publication/309566250_An_Introduction_To_Qualitative_Research_Meth odology_Artistic_Approach.

Barone, Tom, and Liora Bresler. 2000. "Mask-Making as Representational Process: The Situated Composition of an Identity Project in a Senior English Class Article." International Journal of Education \& the Arts 15 (1): 71. https://doi.org/10.1177/1321103X0001500110. 
Budiarto, Antar at. all. 2019. "Relevance Of Value From The Story Of Wayang Beber As A Strengthening In Moral Education Of High School Students Abstract." International Journal of Education and Social Science Research 2 (05): 35-47.

Fitriyani, and Rofiaty Christin Susilowati. 2019. “( Malang Traditional Puppet Mask Dance ) Through Asmorobangun 'S Strategies” 17 (2): 312-18.

Green, Amber, and Myriam Denov. 2019. "Mask-Making and Drawing as Method: Arts-Based Approaches to Data Collection With War-Affected Children." International Journal of Qualitative Methods 18: 113. https://doi.org/10.1177/1609406919832479.

Guntur. 2021. "The Artistry and Creative Process in the Making of Malang Masks in East Java." SPAFA Journal 5: 1-27. https://doi.org/10.26721/SPAFAJOURNAL.2021.V5.636.

Hidajat, Robby, Ahamad Tarmizi, Bin Azizan, and Andy Pramono. 2019. "Transformationof Mask Function From Ritual To Performance Art During Indianization Era in Indonesia" 8 (August): 1-6.

Kieven, Lydia. 2020. "Panji and Sekartaji on the Move." Wacana 21 (1): 69-102. https://doi.org/10.17510/WACANA.V21I1.868.

Kieven, Lydia Christine. 2017. "Getting Closer to the Primordial Panji? Panji Stories Carved in Stone at Ancient Javanese Majapahit Temples - and Their Impact as Cultural Heritage Today." SPAFA Journal 1. https://doi.org/10.26721/spafajournal.v1i0.172.

Novica, Dimas Rifqi, Andy Pramono, Joko Samodra, Mitra Istiar Wardhana, and Ima Kusumawati Hidayat. 2020. "Visual Style Transformation of Wayang Topeng Malang as Urban Toy Design Inspiration." International Journal of Innovation, Creativity and Change 10 (10): 135-46.

Raharjo, Resdianto Permata, Haris Supratno, and Setya Yuwana Sudikan. 2020. "Sosiocultural Symbol in Tengger Mask Puppet Show." PalArch's Journal of Archaeology of Egypt/Egyptology 17 (4): 1158-71.

Rahayuningtyas, Wida, Jazuli Jazuli, Tjetjep Rohendi Rohidi, and Totok Sumaryanto. 2019. "Inheriting the Values of Mask Puppet Dance-Drama in Malang, Indonesia" 327 (Icaae 2018): 285-90. https://doi.org/10.2991/icaae-18.2019.55.

Suprihatin Dyah Pratamawati, Endang Wara. 2016. "Malang Mask Puppet Presentation Structure Arrangement of the Story Rabine Panji as Cultural Tourism Commodity in Malang Regency East Java." Harmonia: Journal of Arts Research and Education $16 \quad$ (1): 66. https://doi.org/10.15294/harmonia.v16i1.6021.

Suprihatin, Endang Wara, and Dyah Pratamawati. 2019. "Conservation Strategy in Preserving The Local Image Existence of Wayang Topeng." Harmonia: Journal of Arts Research and Education 19 (2): 179 84. https://doi.org/10.15294/harmonia.v19i2.24005.

Vaneker, T. H.J. 2017. "Material Extrusion of Continuous Fiber Reinforced Plastics Using Commingled Yarn.” Procedia CIRP 66: 317-22. https://doi.org/10.1016/j.procir.2017.03.367.

Wibowo, Arining. 2019. "Malang Mask Puppet in Era of Globalization: Social and Cultural Impact." Harmonia: Journal of Arts Research and Education 19 (1): 18-28. https://doi.org/10.15294/harmonia.v19i1.16101.

Wibowo, Arining, Joko Kurnain, and Juanda Juanda. 2020. "History of Inheritance of Wayang Topeng Malangan (Malang Traditional Mask Puppet) in Pakisaji and Tumpang." Harmonia: Journal of Arts Research and Education 20 (1): 73-83. https://doi.org/10.15294/harmonia.v20i1.24785. 